\title{
Analisis Pendapatan Pengemudi Ojek Online pada Masa Pandemi Covid- 19 di Kota Salatiga
}

\author{
Heber Andrew Riyan Mallo1*, Paskah Ika Nugroho \\ (iD) \\ ${ }^{123}$ Fakultas Ekonomika dan Bisnis, Universitas Kristen Satya Wacana \\ *232016212@student.uksw.edu ${ }^{I *}$
}

\section{Abstrak}

Go-Jek merupakan perusahaan penyedia layanan transportasi berbasis online yang menggunakan sistem informasi akuntansi. Physical distancing diterapkan untuk menekan penyebaran virus korona oleh pemerintah yang berdampak pada sektor transportasi. Tujuan penelitian ini adalah menganalisis pendapatan pengemudi ojek online perusahaan Go-Jek di kota Salatiga selama masa pandemi COVID-19 dengan dua layanan utama pada masa pandemi yakni Go-Ride dan Go-Food. Penelitian ini melibatkan 20 pengemudi Go-Jek yang telah diwawancarai, 10 pengemudi untuk layanan Go-Ride dan 10 pengemudi untuk layanan Go-Food. Hasil penelitian menunjukan bahwa meskipun pandemi COVID-19 menyebabkan penurunan pendapatan bagi para pengemudi, pengemudi layanan Go-Ride tidak mengalami penurunan yang signifikan dibanding pengemudi layanan GoFood.

Kata kunci : Pendapatan, Sistem Informasi Akuntansi, Pandemi COVID-19

\section{Abstract}

Go-Jek is an online-based transportation service provider that uses an accounting information system. Physical distancing is applied to reduce the spread of the coronavirus by the government which has an impact on the transportation sector. The purpose of this study was to analyze the income of Go-Jek company online drivers in the city of Salatiga during the COVID19 pandemic with two main services during the pandemic, GoRide and GoFood. This study involved 20 Go-Jek drivers who were interviewed, 10 drivers for GoRide services and 10 drivers for GoFood services. The results showed that even though the COVID-19 pandemic caused a decrease in income for drivers, GoRide service drivers did not experience a significant decrease compared to GoFood service drivers.

Keywords: Income, Accounting Information System, COVID-19 Pandemic

\section{Pendahuluan}

Saat ini perkembangan teknologi sudah semakin maju dan bisa diakses oleh berbagai kalangan masyarakat mulai dari usia anak-anak hingga usia dewasa. Pada bidang transportasi juga mendapat sentuhan teknologi, transportasi didefinisikan sebagai kegiatan memindahkan atau mengangkut sesuatu dari suatu tempat ke tempat lain (Nozick \& Morlok, 1997). Saat ini sudah ada bentuk dari hasil kemajuan teknologi disebut dengan istilah transportasi online. Masyarakat tidak perlu untuk bersusah-payah untuk menemukan transportasi umum, karena masyarakat sudah bisa menemukan transportasi secara dan langsung menjemput mereka di titik lokasi yang diberikan melalui sebuah aplikasi di smartphone.

Salah satu transportasi yang banyak digunakan masyarakat sehari-hari untuk melakukan berbagai aktivitas yaitu Ojek online, dibandingkan dengan transportasi lainnya seperti Taxi dan Uber. Ojek online menjadi pilihan utama bagi masyarakat karena menggunakan kendaraan roda dua atau sepeda motor dinilai lebih efektif dan efisien dalam menjemput serta

\footnotetext{
History:

Received: 29 Maret 2021

Revised: 26 Juni 2021

Accepted: 28 Juni 2021

Published: 30 Juni 2021
}

Publisher: Undiksha Press

Licensed: This work is licensed under

a Creative Commons Attribution 3.0 License

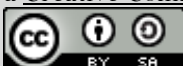


mengantarkan penumpang hingga ke tempat tujuan. Selain bisa melayani antar penumpang, ojek online juga menyediakan layanan pesan antar makanan serta antar barang dan layanan lainnya. Aplikasi yang dibuat perusahaan transportasi online sudah menggunakan sistem informasi akuntansi di dalamnya. Penggunaan sistem informasi akuntansi bertujuan untuk memberikan informasi akuntansi kepada pengguna informasi, baik dari pihak internal atau eksternal.

Pengaruh penggunaan sistem informasi akuntansi terbukti mampu memberikan pengaruh untuk kinerja usaha kecil menengah sebesar 34,5\% pada penelitian yang dilakukan oleh (Indralesmana \& Suaryana, 2014) berjudul "Pengaruh Penerapan Sistem Informasi Akuntansi terhadap Kinerja Individu pada UKM di Nusa Penida". Penelitian yang berjudul "Pemanfaatan Aplikasi Nelayan Pintar di Kabupaten Pati, Jawa Tengah" yang dilakukan oleh (Susilowati, Thohir, SBM, \& Suciati, 2020) juga menunjukkan bahwa aplikasi NelPin yang dibuat Kementerian Kelautan dan Perikanan ingin digunakan oleh para nelayan sangat bermanfaat untuk kegiatan melaut dan mudah untuk dioperasikan. Penggunaan sistem informasi akuntansi pada penelitian yang berjudul "Pengaruh Penerapan Sistem Informasi Akuntansi terhadap Kinerja Karyawan dengan Integritas Karyawan sebagai Variabel Pemoderasi" dilakukan oleh (Dita \& Putra, 2016) di BPR Kabupaten Karangasem, menunjukkan bahwa penerapan sistem informasi akuntansi berpengaruh positif dan signifikan pada kinerja karyawan. Integritas karyawan berpengaruh positif dan signifikan terhadap kinerja karyawan dan integritas karyawan sebagai pemoderasi penerapan sistem informasi akuntansi dan integritas karyawan, menunjukkan integritas karyawan dapat memoderasi.

Pengemudi ojek online di Indonesia sudah mencapai 2,5 juta orang dimana hampir 50\% berada pada wilayah Jabodetabek dan sisanya tersebar di berbagai wilayah lainnya (Azka, 2019). Pendapatan masing-masing pengemudi ojek tergantung pada lokasi pengemudi, jam operasionalnya, dan jarak yang ditempuh pengemudi per kilometer (Ari, 2020). Ada pula faktor lain yang dapat mempengaruhi pendapatan pengemudi ojek, dalam penelitian yang dilakukan oleh (Marsusanti, Susilawati, Nugraha, \& Koeswara, 2018) yang berjudul "FaktorFaktor yang Mempengaruhi Pendapatan Driver Go-Jek" yang dilakukan di Sukabumi dengan jumlah sampel dari 100 orang responden menunjukkan bahwa kenaikan bahan bakar minyak bisa mempengaruhi pendapatan mereka meskipun hanya $25 \%$ dan $75 \%$ sisanya dipengaruhi oleh sistem poin. Adapun juga beberapa faktor yang dapat mempengaruhi pendapatan pengemudi ojek, di dalam penelitian oleh (Giri \& Dewi, 2017) yang berjudul "Analisis Faktor-Faktor yang Mempengaruhi Pendapatan Driver Go-Jek di Kota Denpasar, Bali" menunjukkan bahwa jam kerja dan pengalaman kerja positif mempengaruhi pendapatan para pengemudi Go-Jek. Pendapatan pengemudi ojek online bisa dipengaruhi oleh kebijakan dari perusahaan Go-Jek, berupa lemahnya penerapan Sistem Informasi Akuntansi pada penelitian yang dilakukan oleh (Saputra, 2018) berjudul "Evaluasi Sistem Informasi Akuntansi untuk Mengatasi Risiko Perusahaan (Studi Kasus Driver Go-Jek Kota Bandung)” karena ditemukan kesalahan yang terjadi pada kegiatan operasional di lapangan.

Maret 2020, pemerintah Indonesia resmi menerapkan kebijakan physical distancing (pembatasan jarak antara orang) pada awal Maret 2020 untuk meminimalisir penyebaran COVID-19 yang telah menyebar di beberapa wilayah Indonesia. COVID-19 adalah penyakit menular yang disebabkan oleh jenis virus korona yang baru ditemukan. Virus korona adalah suatu kelompok virus yang dapat menyebabkan penyakit pada hewan atau manusia (World Health Organization, 2020). Akibat pandemi ini, persentase ojek online di Indonesia untuk layanan antar penumpang menurun sebesar $80 \%$, tetapi untuk layanan pesan antar makanan naik $10 \%-20 \%$ (Annur, 2020)

Dampak COVID-19 membuat penurunan di layanan transportasi Go-Jek seperti go-ride dan go-car, karena merupakan layanan yang berinteraksi langsung dengan penumpang. 
Menurut salah seorang pengemudi di kota Semarang, Jawa Tengah, pendapatannya turun hingga $75 \%$. Layanan Go-Jek yang mengalami peningkatan dalam masa pandemi ini adalah gofood dan gosend. Layanan pesan antar makanan dan antar barang ini membuat para pengemudi ojek online mampu bertahan di masa pandemi ini (Sukarno, 2020). Peningkatan dua layanan tersebut terbukti dapat membantu menaikkan pendapatan dari sektor UMKM sebesar $11 \%$ dalam agenda Hari Kuliner Nasional di Semarang, yang berlangsung dari tanggal 1 April hingga 5 Mei 2020 (Rizqi, 2020). Saat masa Lebaran Idul Fitri, terjadi peningkatan orderan gofood di kota Semarang menurut salah satu pengemudi ojek online yang diwawancarai Gubernur Jawa Tengah, Ganjar Pranowo saat melakukan kunjungan di sebuah Mall di kawasan Semarang (Prahastiwi, 2020).

Ojek online di kota Salatiga sebelumnya sangat diminati kalangan pelajar, mahasiswa, dan pekerja. Karena adanya pandemi atau wabah COVID-19 ini, kebijakan physical distancing harus dilakukan oleh semua lapisan masyarakat. Akibatnya penghasilan pengemudi ojek online untuk layanan go-car dan go-ride harus menurun karena UKSW sendiri menerapkan proses perkuliahan dari rumah masing-masing. Tujuan penelitian ini menganalisis pendapatan pengemudi ojek online perusahaan Go-Jek di Kota Salatiga berdasarkan layanan Go-Food dan Go-Ride yang masih beroperasi pada masa pandemi COVID-19, apakah dampak pandemi ini berpengaruh membuat penurunan penghasilan atau memberikan keuntungan bagi pengemudi-pengemudi ojek online tersebut. Manfaat dari penelitian ini bagi pengemudi ojek online diharapkan untuk menjadi bahan pertimbangan untuk tetap atau tidak melanjutkan pekerjaannya sebagai pengemudi ojek online di masa pandemi ini. Manfaat penelitian ini bagi bidang akuntansi yakni dapat dijadikan sebagai bahan referensi atau literatur mengenai kinerja sistem informasi akuntansi pada aplikasi GoJek layanan Go-Ride dan Go-Food untuk penelitian yang terkait. Serta manfaat penelitian ini bagi masyarakat atau para pengguna layanan jasa ojek online untuk tetap saling membantu meringankan pekerjaan masing-masing dalam masa sulit ini.

\section{Pendapatan}

Dalam sebuah pekerjaan pada umumnya seseorang memberikan waktu dan tenaganya untuk bekerja, hasil dari bekerja tersebut biasa disebut pendapatan. Dari pendapatan juga bisa diukur tingkat keberhasilan dan kelangsungan hidup seseorang atau sebuah usaha. Menurut ilmu ekonomi pendapatan adalah nilai maksimum yang digunakan seseorang dalam waktu tertentu dalam kondisi yang sama pada akhir periode dengan keadaan awalnya.

Menurut PSAK 23 (2008) "pendapatan adalah arus masuk bruto dari manfaat ekonomi yang timbul dari aktivitas normal perusahaan selama satu periode jika arus masuk tersebut mengakibatkan kenaikan ekuitas yang tidak berasal dari kontribusi penanam modal"(Ikatan Akuntan Indonesia, 2008, p. 23;06). Pendapatan adalah kenaikan kotor dalam modal pemilik yang dihasilkan dari penjualan barang, menjalankan jasa kepada klien atau juga semua aktivitas usaha profesi yang bertujuan mendapatkan penghasilan (Niswonger, 2006).

\section{Sistem Informasi Akuntansi}

Sistem informasi akuntansi menurut Wilkinson (2000), sistem informasi akuntansi adalah sistem informasi yang mencakup semua fungsi dan aktivitas akuntansi, yang memperhatikan akibat yang akan ditimbulkan pada sumber daya ekonomi dari kejadian eksternal maupun operasi di internal organisasi. Menurut Nugroho Widjajanto (2001), sistem informasi akuntansi adalah susunan formulir, catatan, peralatan termasuk komputer dan perlengkapannya serta alat komunikasi, tenaga pelaksanaannya dan laporan yang terkoordinasi secara erat yang didesain untuk mentransformasikan data keuangan menjadi informasi yang dibutuhkan manajemen.

Dalam menjalankan operasional bisnis, dibutuhkan sistem informasi yang dapat mendukung manajemen suatu perusahaan.

\section{Transaction Processing Systems (TPS)}


Sistem informasi yang terkomputerisasi yang dikembangkan untuk memproses datadata dalam jumlah besar untuk transaksi bisnis rutin seperti daftar gaji dan investasi.

\section{Process Control Systems (PCS)}

Sistem informasi yang bertugas dalam pengendalian seluruh aktivitas operasional.

3. Enterprise Collaboration Systems (ECS)

Sistem informasi yang menghubungkan dan meningkatkan komunikasi, koordinasi dan kerja sama antar sesama dalam suatu perusahaan atau kelompok.

Manajemen dalam menjalankan perusahaan menggunakan bantuan sistem informasi yang akan digunakan sebagai bahan pertimbangan dalam membuat keputusan.

1. Management Information System (MIS)

Sistem informasi yang membuat laporan berisi informasi-informasi kepada manajer.

2.Decision Support System (DSS)

Sistem informasi yang berisi informasi-informasi yang akan dijadikan bahan pertimbangan dalam membuat suatu keputusan.

3. Executive Information System (EIS)

Sistem informasi yang menyediakan informasi-informasi yang bersumber dari eksternal dan internal perusahaan yang akan digunakan oleh para eksekutif atau manajer perusahaan.

Ojek Online

Ojek adalah sebuah transportasi berjenis sepeda motor yang digunakan untuk mengantarkan seorang penumpang ke tempat tujuan, jika telah sampai ke tempat tujuan maka penumpang akan memberikan bayaran berupa uang kepada pengemudi ojek. Ojek menjadi pilihan alternatif ketika tempat tujuan harus melewati jalan yang sedang macet atau tempat tujuan terdapat pada lokasi jalan-jalan yang sempit atau tidak bisa dilewati oleh mobil, bus dan lainnya.

Pada saat ini ojek online sangat diminati masyarakat, karena majunya teknologi saat ini mengaksesnya cukup menggunakan aplikasi yang terdapat pada smartphone yang terhubung dengan jaringan internet. Ojek akan langsung datang menjemput tanpa harus pergi ke tempat umum. Karena kendaraan yang digunakan berjenis sepeda motor, menjadi pilihan utama ketika penumpang sedang terburu-buru atau ingin menghindari kemacetan. Aplikasi penyedia layanan ojek online telah dilengkapi dengan fitur estimasi jarak dan waktu dari tempat asal ke tempat tujuan, penumpang juga dapat mengetahui identitas pengemudi ojek online tersebut dan penumpang juga diberitahu berapa harga yang akan dibayar.

\section{Pendapatan Ojek Online}

Pendapatan salah satu layanan ojek online yaitu Go-Jek mempunyai kesepakatan kerja antara perusahaan dan pengemudi ojek dengan cara bagi hasil pendapatan $20 \%$ untuk perusahaan dan $80 \%$ untuk pengemudi ojek. Namun ada beberapa hal yang sangat berpengaruh dalam penentuan pendapatan pengemudi ojek. Tarif yang diterapkan pada lokasi pengemudi di wilayah Jabodetabek berbeda dengan lokasi pengemudi di wilayah luar Jabodetabek. Tarif per kilometer di jam sibuk (pagi hingga malam hari) dan diluar jam sibuk (dini hari) antara wilayah Jabodetabek dengan luar wilayah Jabodetabek juga berbeda. Apabila pengemudi ojek online menyelesaikan satu orderan, misalkan layanan Go-Car maka pengemudi tersebut akan mendapatkan poin yang nantinya akan ditukar sebagai bonus dan setiap perolehan poin dalam menyelesaikan orderan juga berbeda di wilayah Jabodetabek dan luar Jabodetabek (Ari, 2020).

COVID-19

COVID-19 (Coronavirus Disease-2019) merupakan sebuah penyakit menular yang disebabkan oleh virus korona, penyebaran pertama tercatat oleh World Health Organization (WHO) terjadi di Wuhan, Tiongkok. Virus korona sendiri merupakan penyakit atau virus yang bisa menyerang manusia dan hewan. Penyakit yang disebabkan berupa infeksi pada 
saluran pernapasan. Gejala-gejala yang muncul jika terkena COVID-19 ini adalah: rasa nyeri, sakit, hidung tersumbat, sakit kepala, konjungtivitis, sakit tenggorokan, diare, hilang kemampuan penciuman, ruam pada kulit, perubahan warna kulit pada jari tangan dan kaki

Virus korona dapat menyebar melalui percikan-percikan yang berasal dari mulut atau hidung penderita virus. Untuk mencegah penularan wabah ini semakin meluas, WHO menyarankan setiap pemerintah di negara-negara yang sudah tertular virus tersebut agar membatasi aktivitas masyarakatnya dengan cara tinggal di rumah dan jika ada keperluan mendesak diluar, diwajibkan untuk mengenakan masker dan menjaga jarak dengan orang lain minimal 1,5 meter dan mencuci tangan sebelum atau sesudah melakukan aktivitas.

Social Distancing and Physical Distancing

Saran yang diberikan WHO mengenai cara mencegah penularan virus korona ini adalah dengan menerapkan social distancing yakni membatasi aktivitas masyarakat yang dapat melakukan kontak fisik dengan orang lain, seperti tidak pergi ke keramaian dan dihimbau untuk tinggal di rumah. Dengan cara seperti ini, hampir semua lapangan pekerjaan yang ada ditutup karena kebijakan dari masing-masing pemerintah dalam mengatasi penyebaran wabah virus corona. Tidak ada pekerjaan membuat orang-orang mengalami kesulitan ekonomi hingga pada akhirnya WHO mengganti istilah social distancing dengan physical distancing dimana orang-orang dapat melakukan aktivitas namun tetap dalam pengawasan serta menjaga jarak yang telah dianjurkan minimal 1.5 meter.

\section{Metode}

Jenis penelitian ini menggunakan jenis penelitian kualitatif. Menurut (Sugiyono, 2010) penelitian kualitatif adalah penelitian yang digunakan dalam meneliti pada kondisi objek alamiah, dimana peneliti merupakan instrumen kunci.

Tempat penelitian akan dilakukan di kota Salatiga dengan beberapa titik posisi menunggu orderan yang berbeda antara pengemudi-pengemudi ojek online dan dilaksanakan pada akhir bulan Desember 2020 hingga awal bulan Januari 2021.

Menurut (Riduwan, 2010) teknik pengumpulan data merupakan cara-cara seorang peneliti untuk memperoleh data yaitu wawancara dimana peneliti secara langsung bertatap muka dengan para pengemudi ojek online dan memberikan beberapa pertanyaan yang sudah disiapkan peneliti sebelumnya.

Teknik analisis yang digunakan adalah analisis kualitatif, menurut (Sugiyono, 2007) langkah-langkah analisis kualitatif ada beberapa tahap yakni pengumpulan data (data-data diperoleh dari hasil wawancara), reduksi data (data-data yang telah dikumpulkan selanjutnya akan diperiksa untuk memperoleh data yang berkaitan agar memudahkan dalam mengambil kesimpulan), penyajian data (penyajian data yang digunakan adalah bentuk naratif, dimana data-data disajikan berbentuk informasi yang tersusun sistematis dan dapat dipahami), dan penarikan kesimpulan (data-data yang telah disusun akan dibandingkan dengan data lainnya agar diperoleh kesimpulan)

\section{Hasil dan Pembahasan}

\section{Visi \& Misi Go-Jek}

Membantu memperbaiki struktur transportasi di Indonesia, memberikan kemudahan bagi masyarakat dalam melaksanakan pekerjaan sehari-hari seperti pengiriman dokumen, belanja harian, dengan menggunakan layanan fasilitas kurir, serta turut mensejahterakan kehidupan tukang ojek di Jakarta dan Indonesia kedepannya.

Misi:

1. Menjadikan PT Go-Jek Indonesia sebagai jasa transportasi tercepat dalam melayani kebutuhan masyarakat Indonesia. 
2. Menjadikan PT Go-Jek Indonesia sebagai acuan pelaksanaan kepatuhan dan tata kelola struktur transportasi yang baik dengan menggunakan kemajuan teknologi.

3. Meningkatkan kepedulian dan tanggung jawab terhadap lingkungan dan sosial.

4. Memberikan layanan prima dan solusi yang bernilai tambah kepada pelanggan.

Profil Go-Jek

PT Go-Jek Indonesia merupakan salah satu perusahaan yang menyediakan jasa layanan transportasi online berupa ojek motor di Indonesia. PT Go-Jek Indonesia didirikan sejak tahun 2011 oleh Nadiem Makarim, terletak di Jl. Kemang Timur No. 15, Mampang Prapatan, Kota Jakarta Selatan, Daerah Khusus IbuKota Jakarta. Seiring berjalannya waktu masyarakat mulai meningkatkan minatnya terhadap layanan yang disediakan Go-Jek. (Struktur organisasi Go-Jek dapat dilihat pada lampiran I)

Layanan yang disediakan Go-Jek ada bermacam-macam. Layanan transportasi dan logistik Go-Ride (antar jemput penumpang menggunakan kendaraan roda dua), Go-Car (antar jemput penumpang menggunakan kendaraan roda empat), Go-Bluebird (antar jemput menggunakan armada Blue Bird), Go-Send (antar jemput barang). Layanan makanan dan belanja Go-Food (pesan antar makanan), Go-Med (pesan antar kebutuhan medis), Go-Mart (layanan berbelanja online). Layanan pembayaran Go-pay (dompet digital untuk segala transaksi digital), Go-Tagihan (membayar tagihan apapun), pay later (pembayaran transaksi di akhir bulan), Go-Sure (membantu melindungi, merawat dan memperbaiki peralatan rumah tangga). Layanan berita dan hiburan; GoPlay (streaming dan mengunduh film atau serial); GoTix (memudahkan dalam pembelian atau pemesanan tiket). Pada tahun 2017 PT Go-Jek mulai beroperasi di Kota Salatiga, meskipun pada awal berjalan sempat dikecam oleh pengendara angkutan umum dan ojek pangkalan karena Go-Jek diduga mencuri mata pencaharian mereka. Namun hal ini telah diselesaikan oleh Pemerintah Kota Salatiga dan hingga kini Go-Jek tetap beroperasi.

Kota Salatiga memiliki beberapa sekolah dan perguruan tinggi yang berkualitas, menjadikan hal ini sebagai minat pelajar-pelajar dari luar Salatiga. Para pelajar dalam melakukan aktivitas atau ingin pergi ke tempat sekolah seringkali menggunakan aplikasi GoJek khususnya layanan Go-Ride karena dapat sampai ke tempat tujuan dengan cepat dan menghemat waktu perjalanan. Keberadaan transportasi online ini tidak hanya membantu para pelajar saja, namun juga membantu para pekerja atau pegawai-pegawai kantoran yang ingin pergi ke tempat kerja serta melakukan aktivitas lainnya.

\section{Sistem Informasi Akuntansi Perusahaan Go-Jek}

Go-Jek merupakan salah satu perusahaan yang menggunakan jaringan internet, untuk terhubung dengan pelanggan serta mitra. Menurut Jony Wong (2010: 33), penggunaan sistem elektronik seperti jaringan internet dalam menjalankan bisnis disebut E-commerce. Sistem akuntansi dari Go-Jek tersusun dari diantaranya fasilitas order processing yaitu konsumen melakukan pemesanan jasa, kemudian data yang telah diperoleh akan menentukan jumlah pembayaran. Selanjutnya fasilitas billing dimana jumlah pembayaran kemudian akan dibukukan ke buku besar. Pembayaran yang telah dilakukan pelanggan akan menjadi bukti yang akan disediakan di penerimaan kas pada buku besar. Setiap transaksi yang pelanggan yang menggunakan layanan Go-Jek akan masuk ke dalam pembayaran tunai atau utang yang telah disepakati antara Go-Jek dan pengemudi sebesar $20 \%$ untuk perusahaan dan $80 \%$ untuk pengemudi yang akan dimasukkan ke dalam sistem buku besar Go-Jek.

Dalam menjalankan operasi bisnisnya Go-Jek menggunakan sistem:

\section{Transaction Processing System (TPS)}

TPS akan mencatat dan memproses data yang berasal dari hasil transaksi bisnis untuk digunakan sebagai informasi bagi pihak internal maupun eksternal. Pada Go-Jek TPS berfungsi sebagai pengatur masuk keluarnya transaksi seperti mengestimasi biaya 
perjalanan berdasarkan jarak, harga-harga yang akan dibayar jika ada pengurangan atau pun penambahan dalam menggunakan salah satu layanan Go-jek

\section{Process Control System (PCS)}

PCS mengatur semua kegiatan bisnis agar berjalan sesuai langkah-langkah atau sesuai SOP yang berlaku. Pada saat pelanggan memesan atau menggunakan salah satu layanan Go-Jek, pelanggan akan mengikuti langkah-langkah yang telah tersedia. Mulai dari awal order, pengemudi mengkonfirmasi kepada pelanggan apa yang akan di order hingga penyelesaian order.

\section{Enterprise Collaboration System (ECS)}

ECS digunakan untuk meningkatkan komunikasi, koordinasi dan kolaborasi pihakpihak yang terlibat di dalam kegiatan operasi bisnis. Go-Jek membuat banyak kantorkantor cabang saling terhubung yang tersebar di berbagai wilayah di Indonesia. Go-Jek juga tidak menutup informasi mengenai pengemudi kepada pelanggan dan informasi mengenai pelanggan kepada pengemudi berupa nama, foto, nomor hp agar menciptakan kenyamanan dalam berkomunikasi.

Dalam membantu pengambilan keputusan. Go-Jek menggunakan sistem:

1.Management Information Systems (MIS)

MIS merupakan penyedia laporan informasi bagi pihak manajemen, informasi yang disediakan berasal dari operasi bisnis. Go-Jek menggunakan MIS agar mendapat informasi-informasi khusus mengenai statistik, data orderan, transaksi-transaksi hingga kinerja pengemudi yang bisa diambil dari penilaian bintang yang berikan oleh pelanggan.

\section{Decision Support Systems (DSS)}

DSS merupakan tahap selanjutnya dari MIS dalam membuat keputusan manajemen lanjut. Akibat dari pandemi yang terjadi, pihak Go-Jek menutup sebagian layanan mereka karena tidak dapat beroperasi dan memfokuskan ke beberapa layanan yang menjadi kekuatan bisnis mereka.

\section{Executive Information Systems (EIS)}

EIS merupakan penyedia informasi kepada manajemen eksekutif dengan cepat dan mudah agar menjaga kelangsungan hidup perusahaan. Go-Jek banyak menjalin kerja sama dengan pihak-pihak UMKM untuk layanan Go-Food, bahkan membuat penawaran ataupun diskon dalam setiap orderan agar dapat bersaing dengan perusahaan sejenis.

Teknologi informasi yang digunakan Go-Jek:

1. Teknologi End User :Aplikasi Go-Jek yang tersedia di smartphone Android dan IOS.

2. Teknologi Database : Cloud computing dan penyimpanan pada smartphone.

3. Application Programming Interface (API) : Penggunaan google maps oleh pengemudi.

4. Payment :Pembayaran online melalui Go-Pay.

5. Customer Service : Pelanggan dapat menggunakan jasa customer service yang terdapat pada media sosial, website resmi dan call center.

\section{Layanan Go-Jek pada Masa Pandemi COVID-19}

Pada saat ini Indonesia dan beberapa negara sedang dilanda pandemi virus korona, hal ini sangat berdampak negatif pada perkembangan aktivitas dari sistem perekonomian setiap negara di dunia. Perkembangan COVID-19 sangat cepat tersebar di beberapa negara, Indonesia menjadi salah satu negara yang dilanda oleh pandemi COVID-19. Seluruh aktivitas masyarakat yang bersentuhan fisik atau berinteraksi secara langsung antar sesama masyarakat dilarang pemerintah Indonesia, karena dapat menularkan virus Korona. Pemerintah Indonesia mulai memberlakukan PSBB (Pembatasan Sosial Berskala Besar) sejak Maret 2020 setelah terdapat warga Indonesia yang positif terjangkit virus Korona. Hal ini justru berdampak bagi 
perusahaan-perusahaan karena dilarang beroperasi di masa pandemi COVID-19 dan akibatnya beberapa perusahaan memberlakukan PHK (Pemutusan Hubungan Kerja) terhadap karyawan mereka secara paksa untuk tetap menjaga keuangan perusahaan tetap pada laba.

Pandemi COVID-19 juga berdampak bagi PT Go-Jek Indonesia, hasilnya sekitar 9\% dari total karyawan Go-Jek atau sebanyak 430 karyawan di PHK karena mereka merupakan karyawan layanan Go-Massage (pijat profesional), Go-Life (jasa kebersihan), dan Go-Food Festivals (pusat jajanan serba ada makanan dan minuman di sejumlah lokasi di Indonesia). Layanan-layanan tersebut diberhentikan oleh pihak Go-Jek karena layanan yang ditawarkan menerapkan kontak fisik kepada pelanggan. Sesuai dengan visi dan misi Go-Jek, PT Go-Jek membuat strategi untuk dapat bertahan di tengah pandemi COVID-19 ini dengan cara memfokuskan bisnis inti yang berdampak langsung terhadap masyarakat. Bisnis inti yang dimaksudkan adalah layanan transportasi online Go-Ride dan Go-Car serta Go-Send, layanan makanan Go-Food, dan layanan pembayaran Go-Pay (Kompas.com, 2020). Cara menjalankan orderan pada aplikasi Go-Jek oleh pengemudi (layanan Go-Food dapat dilihat pada lampiran II dan layanan Go-Ride dapat dilihat pada lampiran III)

Data yang dihasilkan merupakan hasil wawancara pengemudi Go-Jek layanan Go-Ride dan hasil wawancara pengemudi Go-Jek layanan Go-Food. Data diperoleh melalui kegiatan penelitian yang dilakukan 2 kali dan melibatkan 10 pengemudi Go-Ride dan 10 pengemudi Go-Food.

Dari hasil wawancara yang dilakukan kepada pengemudi Go-Jek layanan Go-Food, 9 orang telah menjadi pengemudi Go-Jek sebelum memasuki tahun 2020. Sebagian dari mereka ingin bekerja sebagai pengemudi Go-Jek karena tuntutan keadaan atau untuk memenuhi kebutuhan hidup pribadi maupun keluarga. Pada masa pandemi ini mereka tidak berencana untuk mencari pekerjaan lain karena hanya ini satu-satunya pekerjaan mereka tetapi mereka bekerja dengan selalu taat menggunakan protokol kesehatan agar menjaga kesehatan serta mencegah penyebaran virus korona baik terhadap sesama pengemudi dan pelanggan saat melaksanakan orderan.

Mahasiswa menjadi salah satu kalangan yang selalu menggunakan layanan Go-Food baik sebelum pandemi atau pun semasa pandemi. Restoran yang sudah menjalin kerja sama dengan Go-Jek menjadi restoran yang terdapat banyak orderan dibandingkan dengan restoran yang lain tidak bekerja sama. Hal ini dibuktikan dengan naiknya pendapatan bersih yang diterima oleh pengemudi layanan Go-Food yang menunggu datangnya orderan di dekat restoran-restoran yang sudah bekerja sama dengan Go-Jek.

Meskipun telah menjalankan protokol kesehatan dalam bekerja rata-rata pengemudi layanan Go-Food mengalami penurunan order, point dan pendapatan bersih yang cukup signifikan akibat pandemi. Ini menunjukkan bahwa pengaruh pandemi membuat masyarakat mengurangi interaksi dengan sesama dan masih kurang percaya kepada pengemudipengemudi layanan Go-Food.

Dari hasil wawancara pengemudi Go-Jek layanan Go-Ride, 7 pengemudi sangat bergantung pada pekerjaan ini untuk memenuhi kebutuhan hidup mereka. Mereka tetap bekerja pada masa pandemi karena tidak mempunyai pekerjaan lain selain menjadi pengemudi Go-Jek. Menjalankan protokol kesehatan dalam bekerja sudah menjadi SOP dari Go-Jek untuk setiap pegawai atau karyawannya untuk menciptakan kenyamanan kepada pelanggan serta membantu mengurangi penyebaran virus korona (pandemi).

Sebelum terjadi pandemi, para pengemudi layanan Go-Ride dalam bekerja sehari-hari selalu stabil mendapatkan rata-rata 20 orderan per harinya dan mengumpulkan 20 poin per hari dengan pendapatan bersih per hari yang mencapai Rp 150000 hingga Rp 200000 per hari. Tetapi semasa pandemi terjadi penurunan hingga 10 orderan, 10 poin, dan pendapatan yang diterima para pengemudi hanya berkisar antara Rp 50000 - Rp 100000 per hari. Hal ini menunjukkan bahwa pengaruh pandemi membuat perolehan pendapatan pengemudi Go-Jek 
layanan Go-Ride menurun. Masyarakat atau kalangan pelajar, mahasiswa, dan pekerja yang mempunyai kendaraan pribadi lebih memilih untuk menggunakannya sedangkan masyarakat yang tidak punya kendaraan masih tetap menggunakan layanan Go-Ride untuk pergi beraktivitas.Discussion is the most important of scientific articles. The purpose of the discussion is to answer the research problem, interpret the findings from research into a collection of existing knowledge, and develop new theories, or modify existing theories.

\section{Simpulan dan Saran}

Berdasarkan hasil penelitian kualitatif dengan teknik wawancara kepada pengemudi ojek online (Go-Jek) di kota Salatiga, Jawa Tengah tentang pendapatan pengemudi ojek online selama masa pandemi COVID-19 dapat diambil beberapa kesimpulan seperti Bekerja sebagai pengemudi ojek online khususnya Go-Jek pada masa pandemi COVID-19 ini ternyata sangat sulit. Dilihat dari data yang diperoleh peneliti, rata-rata pengemudi Go-Jek mengalami penurunan orderan, penurunan poin, hingga penurunan pendapatan yang bisa di dapat dalam sehari oleh para pengemudi Go-Jek baik pengemudi layanan Go-Ride maupun pengemudi layanan Go-Food. Pengemudi Go-Jek yang sedikit diuntungkan pada masa pandemi yakni pengemudi layanan Go-Ride dibandingkan dengan layanan Go-Food. Penurunan layanan GoRide tidak se signifikan layanan Go-Food, Pada masa pandemi seperti ini, masyarakat kota Salatiga yang sebelumnya menggunakan jasa Go-Jek sebagai transportasi untuk melakukan berbagai aktivitas terbukti kurang menggunakan jasa Go-Jek. Diterapkannya physical distancing oleh pemerintah membuat sebagian masyarakat kota Salatiga lebih berhati-hati dalam melakukan setiap aktivitas di luar rumah.

Adapun saran pada penelitian ini yaitu Pemerintah kota Salatiga membuat sebuah kebijakan yang dapat memberi kesejahteraan bagi pengemudi-pengemudi ojek online yang ada di kota Salatiga pada saat-saat sulit pada masa pandemi ini. Contoh mengajak masyarakat kota Salatiga menggunakan jasa-jasa ojek online.

\section{Daftar Pustaka}

Pengemudi Taksi Dan Ojek Online Anjlok 80\% Akibat Corona. Retrieved June 4, 2020, From Www.Katadata.Co.Id Website: Https://Katadata.Co.Id/Berita/2020/03/30/Pendapatan-Pengemudi-Taksi-Dan-OjekOnline-Anjlok-80-Akibat-Corona

Ari. (2020). Gaji Gojek Terbaru 2020 : Fasilitas \& Perhitungan Gaji Driver Gojek. Retrieved June 4, 2020, From Www.Infojek.Com Website: Https://Www.Infojek.Com/GajiGojek-Terbaru/

Azka, R. M. (2019). Berapa Sih Jumlah Pengemudi Ojek Online? Simak Penelusuran Bisnis.Com! Retrieved June 4, 2020, From Www.Bisnis.Com Website: Https://Ekonomi.Bisnis.Com/Read/20191112/98/1169620/Berapa-Sih-Jumlah-

Pengemudi-Ojek-Online-Simak-Penelusuran-Bisnis.Com

Dita, M., \& Putra, I. (2016). Pengaruh Penerapan Sistem Informasi Akuntansi Terhadap Kinerja Karyawan Dengan Integritas Karyawan Sebagai Variabel Pemoderasi. E-Jurnal Akuntansi.

Giri, P. C., \& Dewi, M. H. U. (2017). Analisis Faktor-Faktor Yang Mempengaruhi Pendapatan Driver Go-Jek Di Kota Denpasar Bali. E-Jurnal EP Unud.

GOJEK. (2020). GOJEK Services. Retrieved June 17, 2020, From Www.Gojek.Com Website: Https://Www.Gojek.Com/

Ikatan Akuntan Indonesia. (2008). Standar Akuntansi Keuangan. Jakarta: Penerbit Salemba 
Empat.

Indralesmana, K. W., \& Suaryana, I. G. N. A. (2014). Pengaruh Penerapan Sistem Informasi Akuntansi Terhadap Kinerja Individu Pada Usaha Kecil Dan Menengah Di Nusa Penida. E-Jurnal Akuntansi.

Kompas.Com. (2020). Fokus Bisnis Inti Jadi Strategi Gojek Bertahan Di Tengah Pandemi. Retrieved From Www.Kompas.Com Website: Https://Money.Kompas.Com/Read/2020/06/24/103128126/Fokus-Bisnis-Inti-JadiStrategi-Gojek-Bertahan-Di-Tengah-Pandemi

Marsusanti, E., Susilawati, S., Nugraha, R., \& Koeswara, T. S. N. (2018). Faktor - Faktor Yang Mempengaruhi Pendapatan Driver Gojek. Swabumi. Https://Doi.Org/10.31294/Swabumi.V6i2.5184

Niswonger. (2006). Prinsip-Prinsip Akuntansi. Artckel Ilmiah.

Nozick, L. K., \& Morlok, E. K. (1997). A Model For Medium-Term Operations Planning In An Intermodal Rail-Truck Service. Transportation Research Part A: Policy And Practice. Https://Doi.Org/10.1016/S0965-8564(96)00016-X

Prahastiwi, A. T. (2020). Curhat Driver Ojek Online Pada Ganjar Pranowo, Saat Lebaran Orderan Akhirnya Meningkat. Retrieved September 3, 2020, From Www.Pikiranrakyat.Com Website: Https://Www.Pikiran-Rakyat.Com/Nasional/Pr01389320/Curhat-Driver-Ojek-Online-Pada-Ganjar-Pranowo-Saat-Lebaran-OrderanAkhirnya-Meningkat

Riduwan. (2010). Dasar Dasar Statistika. Pendidikan Dan Perilaku Kesehatan.

Rizqi, A. N. (2020). Pendapatan UMKM Semarang Naik 11\% Gara-Gara Harkulnas. Retrieved September 3, 2020, From Www.Solopos.Com Website: Https://Www.Solopos.Com/Pendapatan-Umkm-Semarang-Naik-11-Gara-GaraHarkulnas-1063329

Saputra, I. Y. (2018). Evaluasi Sistem Informasi Akuntansi Untuk Mengatasi Risiko Perusahaan: Studi Kasus Driver Go-Jek Kota Bandung. UNPAR Institutional Repository.

Sugiyono. (2007). Metode Penelitian Pendidikan Pendekatan Kuantitatif, Kualitatif, Dan R\&D. Bandung: Alfabeta. Journal of Chemical Information And Modeling. Https://Doi.Org/10.1017/CBO9781107415324.004

Sugiyono. (2010). Metode Penelitian Bisnis. Pendekatan Kuantitatif, Kualitatif Dan R \& D. Bandung: Alfabeta.

Sukarno, P. A. (2020). Ekosistem Digital Gojek Bantu UMKM Bertahan Selama Pandemi Covid-19. Retrieved September 3, 2020, From Www.Bisnis.Com Website: Https://Finansial.Bisnis.Com/Read/20200804/563/1275053/Ekosistem-Digital-GojekBantu-Umkm-Bertahan-Selama-Pandemi-Covid-19

Susilowati, I., Thohir, M., SBM, N., \& Suciati, I. (2020). Pemanfaatan Aplikasi Nelayan Pintar Di Kabupaten Pati - Jawa Tengah. Jurnal Ekonomi Dan Bisnis, 23 (2), 243-262. Https://Doi.Org/Https://Doi.Org/Https://Doi.Org/10.24914/Jeb.V23i2.3113 